\title{
Factors Associated with Successful Treatment among People Living with HIV: A Study in Cotonou Health Center 1 (Benin), 2018
}

\author{
Moussa Bachabi ${ }^{1, *}$, Badirou Aguemon ${ }^{1}$, Fernand Guédou $^{2}$, Rene Keke $^{3}$, Chaffa Oloukoi ${ }^{4}$, \\ Edgard Marius Ouendo 5 \\ ${ }^{1}$ Cotonou Faculty of Health Sciences, (229) Benin \\ ${ }^{2}$ Cotonou Health Center 1, (229) Benin \\ ${ }^{3}$ National Reference Laboratory for HIV, Cotonou, (229) Benin \\ ${ }^{4}$ National AIDS Control Program, Cotonou, (229) Benin \\ ${ }^{5}$ Regional Institute of Public Health, Ouidah, (229) Benin
}

Received January 28, 2020; Revised March 26, 2020; Accepted April 19, 2020

Copyright $\mathrm{C} 2020$ by authors, all rights reserved. Authors agree that this article remains permanently open access under the terms of the Creative Commons Attribution License 4.0 International License

\begin{abstract}
The aim of the study was to identify factors associated with successful HIV treatment amongst cases seeking care and treatment in Cotonou Health Center 1. This was a crossectional study design in which 297 people living with HIV (PLWH) enrolled for care and treatment at the Cotonou Health Center, were followed over a period of 13 months from November 2017 to December 2018. Cotonou 1 Health Center, is a reference center for the treatment and care of the people living with HIV and key populations in Benin. The objective was to identify the factors associated with the therapeutic success at the Cotonou 1 Health Center. The average age of the respondents was $42.60 \pm 10.69$ years with extremes ranging from 19 to 78 years; the average weight was 61.13 $\pm 13.50 \mathrm{~kg}$ with extremes ranging from 37 to $115 \mathrm{~kg}$. Successful HIV treatment has been defined by a $\mathrm{VL}<1000$ copies $/ \mathrm{ml}$. The main factors associated with successful HIV treatment were geographical accessibility, age, gender, socio-economic level, whether or not traditional medicine is used, adherence to treatment, the value of CD4 to initiation of ARV treatment and reception. Four potential predictors have been identified by the logistic regression model: economic level $(\mathrm{p}<5 \%)$; compliance $(\mathrm{p}<10 \%)$; age $(\mathrm{p}<5 \%)$ and sex $(\mathrm{p}<5 \%)$. To conclude our study, we can say that the UNAIDS 90-90-90 targets will be achieved by 2020 in Cotonou I Health center. However, this center need to improve on crucials factors identified during our study such as economic level, compliance of patients and sensitization of young people (15-24 years) and male to reach this goal.
\end{abstract}

Keywords HIV, PLWHIV, Antiretroviral Therapy,
Therapeutic Success, Cotonou

\section{Introduction}

In 2017, there were approximately 36.9 million people living with HIV worldwide, including 1.8 million new infections. With more than 35.4 million deaths to date, HIV continues to be a major global public health problem. Sub-Saharan Africa, where 26 million people were living with HIV in 2017, is the most affected region. Of those who had access to treatment, $81 \%$ had their viral load suppressed globally; 75\% in central and West Africa and $71 \%$ in Benin (2018 global statistics, WHO). Individual HIV viral load is the recommended indicator to evaluate the effectiveness of antiretroviral treatment, the level of adherence to HIV treatment and therefore the existence of risk of HIV transmission (WHO, 2016). The baseline viral load for treatment failure or success is 1,000 copies $/ \mathrm{ml}$ in accordance with the consolidated guidelines on the use of antiretroviral drugs in the treatment and prevention of HIV infections (WHO, 2016). Indeed, people with viral load below the threshold of 1,000 should be considered as having suppressed viral loads. The objective of this study was to identify and analyze the factors associated with the therapeutic success at the Cotonou 1 Health Center in Benin.

\section{Materials and Methods}

The study was carried out at the Cotonou 1 Health 
Center. Cotonou 1 Health Center is a reference health center in management and monitoring of key populations (sex workers, men who have sex with other men). This was cross-sectional study conducted over a 13-month period (November 2017 to December 2018) in which 297 people living with HIV (PLWH) and seeking care and treatment at the Cotonou 1 Health Center, were followed. The study has enrolled PLWHIV initiated at HIV treatment for at least six months who attended this center during the data collection period. The sample consists of people who came for antiretroviral treatment intake or routine medical visit. All patients who met the inclusion criteria were systematically enrolled. The sample size calculation used the Schwartz formula. Thus, the minimum size required was 288 patients. Data collection was based on a pre-tested questionnaire. Enrolled patients were tested for HIV viral load and classified into two groups: patients with therapeutic success (VL under 1000 copy $/ \mathrm{ml}$ ) and patients with no therapeutic success (VL beyond 1000 copies $/ \mathrm{ml}$ ). Data were captured and analyzed using Epi Data and SPSS version 20.0 software. Bivariate analyses and logistic regression were performed to identify associated and potential predictors of therapeutic success. The significance level of $5 \%$ was considered to retain the significant variables and the strength of the association was measured by the calculation of the rating ratios.

\section{Ethical Considerations}

The study protocol has been submitted to the National Ethics Committee for Health Research in Benin. The favorable opinion of the Ethics Committee was obtained under $\mathrm{N}^{\circ} 15$ on 30 May 2018.

\section{Results}

\subsection{Socio-Demographic Characteristics}

Table 1 below presents other socio-demographic characteristics of the respondents. A total of 297 patients were enrolled in the study. Of the 297 participants, $69 \%$ were females, giving a male to female ratio of 0,45 . The majority $(71 \%)$ were in the age bracket of 25 to 49 years. The ages of the respondents ranged from 19 years to 78 years, with an average of 42.60 ( \pm 10.69 years). The weight of the respondents ranged from 37 to $115 \mathrm{~kg}$ with the average weight of $61.13 \pm 13.50 \mathrm{~kg}$. Those who had primary level of education (35\%) was the most represented followed by $26 \%$ who reported that they had not formal educations. The majority (64\%) of the respondents indicated that they were living a distance of more than $5 \mathrm{~km}$ from health center of Cotonou 1. 
Factors Associated with Successful Treatment among People Living with HIV:

A Study in Cotonou Health Center 1 (Benin), 2018

Table 1. Socio-demographic characteristics, PLWHIV, the Cotonou 1 Health Center, Benin, November 2017 to December 2018

\begin{tabular}{|c|c|c|c|}
\hline \multirow[b]{2}{*}{$\operatorname{Sex}(n=297)$} & \multirow[t]{2}{*}{$\mathbf{N}$} & \multicolumn{2}{|c|}{ Frequency $(\%)$} \\
\hline & & & \\
\hline & Male & 93 & 31 \\
\hline & Female & 204 & 69 \\
\hline \multicolumn{4}{|l|}{ Age $(n=297)$} \\
\hline & $15-24$ & 14 & 5 \\
\hline & $25-49$ & 212 & 71 \\
\hline & 50 et + & 71 & 24 \\
\hline \multicolumn{4}{|c|}{ Marital status $(n=292)$} \\
\hline & Single or divorced or widow & 163 & 56 \\
\hline & Married or monogamous couple & 87 & 30 \\
\hline & Married or in polygamous home & 36 & 12 \\
\hline & Other & 6 & 2 \\
\hline \multicolumn{4}{|c|}{ Education level $(n=297)$} \\
\hline & Not educated & 77 & 26 \\
\hline & Literate & 6 & 2 \\
\hline & Primary level & 104 & 35 \\
\hline & Secondary level & 82 & 28 \\
\hline & Higher level & 28 & 9 \\
\hline \multicolumn{4}{|c|}{ Occupation $(n=289)$} \\
\hline & Student & 8 & 3 \\
\hline & Housewife/farmer & 104 & 36 \\
\hline & Trader & 46 & 15 \\
\hline & Artisan/artist & 74 & 26 \\
\hline & Civil servant/salaried employee & 41 & 14 \\
\hline & Sex workers & 16 & 6 \\
\hline \multicolumn{4}{|c|}{ Religion $(n=291)$} \\
\hline & Catholic Christian & 130 & 45 \\
\hline & Other Christian & 100 & 34 \\
\hline & Muslim & 40 & 14 \\
\hline & Traditional religion & 10 & 3 \\
\hline & Non believer & 6 & 2 \\
\hline & Other & 5 & 2 \\
\hline \multicolumn{4}{|c|}{ Geographic accessibility $(n=292)$} \\
\hline & $>=5 \mathrm{KM}$ & 188 & 64 \\
\hline & $<5 \mathrm{KM}$ & 104 & 36 \\
\hline
\end{tabular}




\subsection{Family Life and Supporting Network for PLWHIV}

Table 2 presents the distribution of PLWHIV by family life and supporting networks. The majority (88\%) of respondents were not members of any PLWHIV association.

Table 2. Distribution of PLWHIV by family life and supporting network, PLWHIV, the Cotonou 1 Health Center, Benin, November 2017 to December 2018

\begin{tabular}{|c|c|c|}
\hline & $\mathbf{n}$ & Frequency (\%) \\
\hline \multicolumn{2}{|l|}{ Family network $(n=296)$} & \\
\hline Lives alone & 73 & 25 \\
\hline Lives as couple & 59 & 20 \\
\hline Lives with an extended family & 84 & 28 \\
\hline Lives as a couple with children & 39 & 13 \\
\hline Lives with the friends & 2 & 1 \\
\hline Other & 39 & 13 \\
\hline \multicolumn{3}{|l|}{ Social network $(n=285)$} \\
\hline Not member of an association & 252 & 88 \\
\hline Passive member & 15 & 5 \\
\hline Active member & 13 & 5 \\
\hline Head of an association & 5 & 2 \\
\hline
\end{tabular}

\subsection{Type of PLWHIV Population Surveyed}

The following figure shows the distribution of respondents by type of population belonging

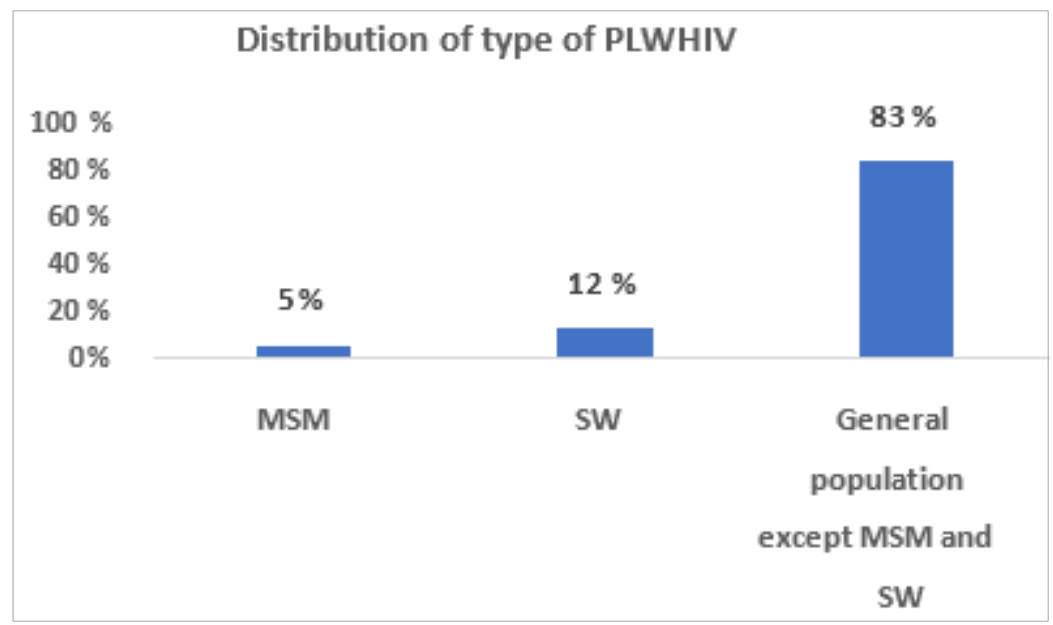

Figure 1. Distribution of PLWHIV by type of population, PLWHIV, the Cotonou 1 Health Center, Benin, November 2017 to December 2018

Majority (83\%) of PLWIHV were from general population, while Sex Workers were $12 \%$ and Men who have Sex with Men 5\%

\subsection{Factors Explaining Therapeutic Success among Surveyed PLWHIV}

The treatment success rate for this study is $\mathbf{7 9 \%}$. The tables below show the relationships between therapeutic success and the independent variables of the study. 
Factors Associated with Successful Treatment among People Living with HIV:

A Study in Cotonou Health Center 1 (Benin), 2018

Table 3. Relationship between therapeutic success and socio-demographic determinants

\begin{tabular}{|c|c|c|c|c|c|}
\hline & \multicolumn{4}{|c|}{ Therapeutic success } & \multirow{3}{*}{$\mathbf{P}$} \\
\hline & \multicolumn{2}{|c|}{ Yes } & \multicolumn{2}{|c|}{ No } & \\
\hline & $\mathbf{n}$ & $\%$ & $\mathbf{n}$ & $\%$ & \\
\hline Age $(n=293)$ & & & & & $\mathbf{0 , 0 3 7}$ \\
\hline $15-24$ years & 7 & 58 & 5 & 42 & \\
\hline $25-49$ years & 165 & 78 & 46 & 22 & \\
\hline 50 years or + & 60 & 86 & 10 & 14 & \\
\hline Sex $(n=292)$ & & & & & 0,048 \\
\hline Female & 162 & 80 & 41 & 20 & \\
\hline Male & 69 & 78 & 20 & 22 & \\
\hline Education level $(n=292)$ & & & & & 0,266 \\
\hline Not educated & 62 & 81 & 15 & 19 & \\
\hline Literate & 4 & 67 & 2 & 33 & \\
\hline Primary level & 27 & 64 & 27 & 26 & \\
\hline Secondary level & 66 & 81 & 15 & 19 & \\
\hline Higher level & 23 & 92 & 2 & 8 & \\
\hline Religion $(\mathbf{n}=\mathbf{2 8 8})$ & & & & & $\mathbf{0 , 8 4 5}$ \\
\hline Catholic Christian & 104 & 81 & 25 & 19 & \\
\hline Other Christian & 77 & 78 & 22 & 22 & \\
\hline Muslim & 32 & 82 & 7 & 18 & \\
\hline Traditional religion & 2 & 20 & 2 & 20 & \\
\hline Non believer & 4 & 67 & 2 & 33 & \\
\hline Other & 3 & 60 & 2 & 40 & \\
\hline Geographic accessibility $(n=289)$ & & & & & 0,011 \\
\hline$<5 \mathrm{KM}$ & 72 & 71 & 30 & 29 & \\
\hline$>=5 \mathrm{KM}$ & 156 & 83 & 31 & 17 & \\
\hline Economic level $(n=289)$ & & & & & 0,04 \\
\hline Very low & 64 & 72 & 25 & 28 & \\
\hline Low & 126 & 80 & 31 & 20 & \\
\hline Average & 38 & 88 & 4 & 9 & \\
\hline
\end{tabular}

Table 4. Relationship between therapeutic success and the PLWHIV network (family, social and population type)

\begin{tabular}{|c|c|c|c|c|c|}
\hline & \multicolumn{4}{|c|}{ Therapeutic success } & \multirow{3}{*}{$\mathbf{P}$} \\
\hline & \multicolumn{2}{|c|}{ Yes } & \multicolumn{2}{|c|}{ No } & \\
\hline & $\mathbf{n}$ & $\%$ & $\mathbf{n}$ & $\%$ & \\
\hline Type of population $(n=293)$ & & & & & $\mathbf{0 , 4 1 2}$ \\
\hline General population & 190 & 79 & 52 & 21 & \\
\hline SW & 32 & 86 & 5 & 14 & \\
\hline MSM & 10 & 71 & 4 & 29 & \\
\hline Family network $(\mathrm{n}=\mathbf{2 9 3})$ & & & & & $\mathbf{0 , 1 7 6}$ \\
\hline Lives with an extended family & 59 & 70 & 25 & 30 & \\
\hline Lives alone & 61 & 84 & 12 & 16 & \\
\hline Lives as a couple without children & 47 & 81 & 11 & 19 & \\
\hline Lives in a couple with children & 31 & 79 & 8 & 21 & \\
\hline Other & 34 & 87 & 5 & 13 & \\
\hline Social network $(n=283)$ & & & & & 0,395 \\
\hline Not member of an association & 201 & 80 & 51 & 20 & \\
\hline Passive member & 10 & 67 & 5 & 33 & \\
\hline Active member & 9 & 69 & 4 & 31 & \\
\hline Head of an association & 3 & 100 & 0 & 0 & \\
\hline
\end{tabular}


Table 5. Relationship between therapeutic success and factors that may influence ART intake

\begin{tabular}{|c|c|c|c|c|c|}
\hline & \multicolumn{4}{|c|}{ Therapeutic success } & \multirow{3}{*}{$\mathbf{P}$} \\
\hline & \multicolumn{2}{|c|}{ Yes } & \multicolumn{2}{|c|}{ No } & \\
\hline & $\mathbf{n}$ & $\%$ & n & $\%$ & \\
\hline HIV status disclosure $(n=291)$ & & & & & 0,981 \\
\hline Yes & 158 & 79 & 42 & 21 & \\
\hline No & 72 & 79 & 19 & 21 & \\
\hline Therapeutic education $(n=292)$ & & & & & 0,289 \\
\hline Yes & 228 & 79 & 59 & 21 & \\
\hline No & 3 & 60 & 2 & 40 & \\
\hline Perception of HIV infection ( $\mathrm{N}=\mathbf{2 9 2})$ & & & & & $\mathbf{0 , 2 1}$ \\
\hline Infectious disease & 161 & 83 & 33 & 17 & \\
\hline Don't know & 52 & 73 & 19 & 27 & \\
\hline Witchcraft & 12 & 71 & 5 & 29 & \\
\hline Curse & 7 & 70 & 3 & 30 & \\
\hline Attending physician $(n=291)$ & & & & & $\mathbf{0 , 5 5 3}$ \\
\hline Senior physician & 71 & 81 & 17 & 19 & \\
\hline Other physician & 159 & 78 & 44 & 22 & \\
\hline Use of traditional medicine $(n=291)$ & & & & & 0,049 \\
\hline No & 207 & 81 & 50 & 19 & \\
\hline Yes & 23 & 68 & 11 & 32 & \\
\hline reception by PLWHIV $(n=291)$ & & & & & 0,05 \\
\hline Very satisfied & 171 & 80 & 43 & 20 & \\
\hline Satisfied & 54 & 81 & 13 & 19 & \\
\hline Moderately satisfied & 4 & 40 & 6 & 60 & \\
\hline Care $(n=291)$ & & & & & 0,409 \\
\hline Very satisfied & 149 & 81 & 36 & 19 & \\
\hline Satisfied & 64 & 74 & 22 & 26 & \\
\hline Moderately satisfied & 3 & 15 & 3 & 15 & \\
\hline
\end{tabular}

Table 6. Relationship between therapeutic success, treatment adherence, treatment protocol and CD4 value at antiretroviral treatment initiation

\begin{tabular}{|c|c|c|c|c|c|}
\hline & \multicolumn{4}{|c|}{ Therapeutic success } & \multirow{3}{*}{$\mathbf{P}$} \\
\hline & \multicolumn{2}{|c|}{ Yes } & \multicolumn{2}{|c|}{ No } & \\
\hline & $\mathbf{n}$ & $\%$ & $\mathbf{n}$ & $\%$ & \\
\hline Adherence to ART treatment $(n=291)$ & & & & & $\mathbf{0 , 0 3 8}$ \\
\hline Adherence ( 0 omission $)$ & 177 & 82 & 39 & 18 & \\
\hline Not adherence ( $>=1$ omission) & 54 & 72 & 21 & 72 & \\
\hline Number of CD4 at ART initiation $(n=272)$ & & & & & 0,001 \\
\hline 0 to 200 & 92 & 70 & 40 & 30 & \\
\hline 200 to 350 & 64 & 93 & 5 & 7 & \\
\hline 350 to 500 & 23 & 77 & 7 & 23 & \\
\hline > 500 & 36 & 88 & 5 & 12 & \\
\hline ART scheme $(n=292)$ & & & & & 0,198 \\
\hline $\mathrm{TDF}+3 \mathrm{TC}+\mathrm{EFV}$ & 126 & 81 & 30 & 19 & \\
\hline $\mathrm{AZT}+3 \mathrm{TC}+\mathrm{NVP}$ & 44 & 79 & 12 & 21 & \\
\hline $\mathrm{ATZ}+3 \mathrm{TC}+\mathrm{EFV}$ & 37 & 86 & 6 & 14 & \\
\hline $\mathrm{TDF}+3 \mathrm{TC}+\mathrm{NVP}$ & 12 & 60 & 8 & 40 & \\
\hline $\mathrm{TDF}+3 \mathrm{TC}+\mathrm{LVP}-\mathrm{r}$ & 9 & 64 & 5 & 36 & \\
\hline $\mathrm{AZT}+3 \mathrm{TC}+\mathrm{LVP}-\mathrm{r}$ & 3 & 100 & 0 & 0 & \\
\hline
\end{tabular}


A statistically significant association was found between treatment success and geographic accessibility, quality of reception, use of traditional medicine, CD4 values at initiation to ART, age, adherence to ART, economic level and gender of PLWHIV surveyed. PLWHIV located more than $5 \mathrm{~km}$ from Cotonou 1 health center are more likely to have therapeutic success than those located less than $5 \mathrm{~km}$ away. Older ages were found to be associated with treatment success. Other factors that were found to be significantly associated with treatment success were being high socioeconomic powers and, absence of history of use of traditional medicine in the patient's treatment pathway. It was also found that PLWHIV who were initiated at CD4 values between 200 and 350 and those who adhered well to ART treatment were more likely to have treatment success. Finally, a good reception of PLWHIV at the health center seems to promote therapeutic success. Although the findings indicate that the proportion of the key populations such as Sex Workers with treatment success was higher than the PLWHIV in the general population, this difference was not statistically significant $(\mathrm{P}=0.412)$.

Based on the step-by-step modelling approach, first testing the interactions and then the potential confounding variables, the final model we arrived at is presented in the table below.

Table 7. Multivariate model of potential predictors of therapeutic success

\begin{tabular}{|c|c|c|c|c|}
\hline Independent variables & $\mathbf{N}$ & OR & $95 \%$ IC & $\mathbf{P}$ \\
\hline Age & & & & $0,041^{*}$ \\
\hline $15-24$ years & 11 & 1 & & \\
\hline $25-49$ years & 187 & 4,083 & {$[1,033-16,134]$} & \\
\hline 50 and over & 63 & 6,799 & {$[1,528-30,250]$} & \\
\hline Adherence to ART & & & & $0,071 * *$ \\
\hline Not adherence & 65 & 1 & & \\
\hline Adherence & 196 & 1,884 & {$[0,947-3,747]$} & \\
\hline Economic level & & & & $0,048 *$ \\
\hline Very low & 81 & 1 & & \\
\hline Low & 141 & 1,823 & {$[0,935-3,552]$} & \\
\hline Average & 39 & 3,644 & {$[1,117-11,888]$} & \\
\hline Sex & & & & $0,044 *$ \\
\hline Male & 82 & 1 & & \\
\hline Female & 179 & 2,404 & {$[1,023-5,650]$} & \\
\hline
\end{tabular}

\footnotetext{
$*=\mathrm{p}$ significant at risk $\alpha$ de $5 \%$; * = p significant at risk $\alpha$ de $10 \%$
} 
According to this model, being female $(\mathrm{p}<0.05)$ is more associated with treatment success than being male; female PLWHIV were found to be 2.4 times more likely to have therapeutic success than male. Also, the economic level is crucial in therapeutic success, the probability for a PLWHIV to have therapeutic success is high when he has a good economic level $(\mathrm{p}<0.05)$. In other words, PLWHIV who have low socio-economic status are 1.8 times more likely to have therapeutic success than those at a very low economic level and also those at an average economic level are 3.6 times more likely to have a therapeutic success than those of very low economic level. Adherence to antiretroviral treatment was found to be associated with therapeutic success $(\mathrm{p}<0.1)$. A PLWHIV who adhered to ART were 1.9 times more likely to have therapeutic success than PLWHIV not adherent. The PLWHIV who were in the age group of 25-49 years were found to be 4 times more likely to have therapeutic success than those in the age group of 15-24 years. PLWHIV over the age of 50 were 7 times more likely than PLWHIV in the 15-24 age group to have therapeutic success $(p<0.05)$.

\section{Discussion}

The bivariate analysis identified eight factors associated with therapeutic success in Cotonoul health center. These include the geographic accessibility of PLWHIV, age, sex, socio-economic status, use of traditional medicine, adherence to treatment, CD4 values at initiation of ART and patient reception. Among these factors the logistic regression allowed to retain mainly socioeconomic level, adherence to treatment, age and sex. This conclusion is not shared by Sheehan DM et al who have shown that viral load suppression does not take into account differences in age, sex, mode of HIV transmission, stage of AIDS diagnosis, socio-economic status, urban or rural residency of PLWHIV.

This study, on the other hand, notes that predictors of poor care retention and viral suppression appear to differ by race and ethnicity [1]. For Detsis M. et al, lack of social support and alcohol are the factors most associated with adherence to treatment and therefore therapeutic success [2]. Siefried K. et al, on the other hand, have found an association between social, economic, cultural factors and therapeutic success [3]. Many authors cited adherence as a therapeutic success factor for PLWHIV [4,5,2]. The same finding was made by Emmanuel N. et al (2015) who cited adherence to ART treatment regardless of sex, age and previous immune status as a factor associated with therapeutic success for PLWHIV [6]. Ferreira C. and Gay M.C. found similar findings [6]. This association was also found by our study. Indeed, a PLWHIV adherent to ART is 1.9 times more likely to have a therapeutic success than a PLWHIV non-adherent according to the results of our study. This is easily understood if it is viewed within the general framework of the management of any pathology where it is known that a person can heal from a disease for which there is a curative treatment, which should be taken in accordance with necessary doses per day and within the duration of treatment. The same findings were made in several studies which have shown that adherence is a major factor in the success of antiretroviral treatment $[7,8,9]$. Adherence below $95 \%$ is associated with immunological and virologic failure.

Economic power is also a key factor for the therapeutic success of PLWHIV according to the findings of this study which showed that as the economic power of PLWHIV increases, the likelihood therapeutic success increases. Siefried K. et al reached similar identified samely the economic factors as determinants of therapeutic success [3]. If it is known that although the support to PLWHIV is free in Benin according to the policy document, standards and support procedures, this free of charge does not cover all benefits, namely certain medicines for the management of opportunistic infections, related costs such as transport, food and certain biological tests [4]. All of these restrictions can contribute to non-adherence to antiretroviral treatment and, therefore, to the failure to achieve therapeutic success. It is then very easy to understand that the economic power of PLWHIV can be crucial for therapeutic success.

Sheehan DM et al demonstrated that viral load suppression does not consider differences in the age and gender of PLWHIV [1]. However, in our study, these two variables were identified as determinants of therapeutic success in PLWHIV followed-up at Cotonoul health center. Regardless of our study, there is evidence that women are fortunate to come into natural contact with the health system through prenatal consultations and therefore benefit from early diagnosis of HIV infection. They could thus benefit from an adapted treatment very early on whereas men could be tested at a late stage, thus compromising their chance of having a therapeutic success because it has been shown that the earlier one starts treatment, the better the result [10]. Our study came up with similar results in demonstrating that PLWHIV who started treatment at CD4 number above 200 cells $/ \mathrm{ml}$ are more likely to have therapeutic success than others. In terms of age, although the literature review did not allow us to have papers that specifically cited age as a determinant of therapeutic success, other cited socio-demographic characteristics overall as determinants of therapeutic success. If we know that awareness grows with age, it would be easy to understand that the older the PLWHIV gets, the more aware he is of his illness and the better his adherence to treatment will be, and therefore this could promote therapeutic success.

\section{Conclusions}

To conclude our study, we can say that the UNAIDS 
90-90-90 targets will be achieved by 2020 in Cotonou I Health center. However, this center need to improve on crucials factors identified during our study such as economic level, compliance of patients and sensitization of young people (15-24 years) and male to reach this goal.

Despite the limitations associated with this study and especially the information biases, the results we have achieved are largely similar to those from the literature review.

\section{Acknowledgements}

The authors express their sincere gratitude to the patients of the Cotonou 1 Health Center who have agreed to participate voluntarily in the development of this work. Also, a deep thank to the staff of the PSLS and to the staff of the reference laboratory of the PSLS for their support.

\section{Conflict of Interest}

The authors stated that there was no conflict of interest.

\section{REFERENCES}

[1] Sheehan DM et al. Retention dans les soins du VIH et la suppression virale: prédicteurs des differences ethniques, individuelles et de voisinage, Floride, avril 2017; 31 (4): $167-175$

[2] J Clin. Factors associated with therapeutic success in HIV-positive individuals in southern Brazil. Pharm Ther. 2015 Apr; 40(2): 192-5

[3] Siefried KJ et al. Les facteurs socioéconomiques expliquent l'adherence sous-optimale a la thérapie antirétrovirale chez les adultes australiens infectes par le VIH avec une suppression virale, avril 2017; 12 (4): 47- 58

[4] PNLS, (2016). Document de Politique, Normes et Procédure de Prise en Charge des PVVIH au Bénin

[5] Detsis $\mathrm{M}$ et al. Facteurs associes au dépistage du VIH et a l'adhésion au traitement du VIH : une revue systématique

[6] Emmanuel N. et al. Facteurs associés a la non observance thérapeutique des sujets adultes infectes par le VIH sous antirétroviraux dans un hôpital de reference à Douala. 2015 (En ligne). Disponible sur URL: <https://www.ncbi.nlm.ni h.gov/pme/articles/PMC4236842/>.Consulté le 20/04/2018

[7] Silveira MP, Maurer P, Guttier MC, Moreira LB. Facteurs associés au succès thérapeutique chez les personnes seropositives du sud du Brésil. Avril 2015; 40 (2): 192-5

[8] Montaner J, Hogg R, Yip B, Wood E, Harrigan R, O'Shaughnessy J. Further characterizing determinants of disease progression among HIV-1 infected patients initiating triple drug therapy. IAS Conf HIV Pathog Treat. Jul 2001; 8-11; 1st: Abstract No LB-O10
[9] Le Moing $\mathrm{V}$ et al. Clinical, biologic, and behavioral predictors of early immunologic and virologic response in HIV-infected patients initiating protease inhibitors. J Acquir Immune Defic Syndr. 2001 ; 27(4) : 372-376. [PubMed]

[10] Myron S. et al. L'initiation précoce de la thérapie antirétrovirale a réduit les taux de transmission sexuelle. Prevention of HIV-1 Infection with Early Antiretroviral Therapy. The new England journal of medicine. august 11, 2011 vol. 365 no. 6 